\title{
Effect Of Processed Cassava Peel Meal On The Haematology Of Pullets
}

\author{
C.O. Ajuonuma ${ }^{1}$ and C.I. Uchendu ${ }^{2}$ \\ ${ }^{I}$ Department of Animal Breeding and Physiology, University of Agriculture, Makurdi \\ ${ }^{2}$ Department of Veterinary Physiology and Pharmacology, University of Nigeria, Nsukka
}

\begin{abstract}
Haematological characteristics was studied in 108 Dominant black pullets fed diets with varying levels of cassava peel meal (CPM). The birds were assigned into three experimental groups; $A, B \& C$ comprising 36 pullets each. The first group, Group A was given the control diets containing $0 \%$ CPM, while Groups $C$ and B diets contained $10 \%$ and $20 \%$ CPM respectively. The packed cell volume (PCV) values in diet $C$ at the $37^{\text {th }}$ week was significantly higher $(P<0.05)$ than the value recorded in the control diet, while the total white blood cell counts in diet $B$ in the 12 week declined significantly $(P<0.05)$ when compared with diet $C$. Diets did not affect the Haemoglobin concentration $(\mathrm{Hb})$. The red blood cells of the pullets showed no significant $(P>0.05)$ difference among the various treatments.
\end{abstract}

\section{Introduction}

The recent global escalation of food crises call for sober reflection, owing to the fact that the world is facing a worsening food crises period unseen in the last 30years and that has a potential of leading to a catastrophe. Nigeria's population growth rate of over 3\% per annum far outstrips the less than $2 \%$ annual growth in food production. Whereas her population increased at an annual rate of between $3 \%$ and $3.32 \%$, total food production rose by no more than an average of $1.5 \%$ per annum between 1983 and 1990 (World Bank, 1988; 1995), and 1.03\% per annum between 1990 and 2000 (CBN, 2002). The strong correlation that has been established between Nigeria's total GDP and the agriculture GDP suggests that the prospects of the non-oil subsector and the overall economy are closely tied to the performance of the agricultural sector (Eboh, 2005). One of the alternatives to partial replacement of maize in animal diets is processed cassava peel meal (Abu and Onifade, 1996; Ikurior and Onu, 1996; Eruvbetine et al., 1996; Salami 1999 and 2000). Aside from the lower values of crude protein and energy of the peel relative to those of maize, the greatest limitation to the use of cassava peels as a substitute for maize is that of it's hydrocyanic acid (HCN) content which is harmful to the monogastrics. Several processing methods have been applied to fresh cassava peels to reduce the cyanide content. The levels of various substances in the blood can provide clues to the animals condition. The best indicator of animals well being and it's potential for production is it's health status. Haematological profiles are important indicators of health and disease in animals and have become indispensable in the diagnosis, treatment and prognosis of many diseases.

\section{Materials and Methods}

This experiment was carried out in Makurdi, Benue State, Nigeria. Dominant black pullet chicks for this research were purchased from Global Millennium Chicks Hatchery in Ibadan, Nigeria. One hundred and eighty pullets were used in this research. The pullets were housed in an open-sided poultry house, which was partitioned into homogenous pens. The experimental diets consisted of a control diet without cassava peel meal; $\mathrm{T}_{1}(0 \%)$ and others containing cassava peel meal at graded levels; $\mathrm{T}_{2}(10 \%)$ and $\mathrm{T}_{3}(20 \%)$ respectively. After soaking the cassava peels inside a closed metal drum for 5 days, the peels were removed from the sticky water and drained with a basket and subsequently sun-dried for $3-5$ days. Haematological parameters determined included the packed cell volume (PCV), haemoglobin $(\mathrm{Hb})$ concentration, total white bl.ood cell counts (total leucocytes count). Blood was collected from the jugular vein of the pullets into clean dry glass tubes containing a pinch of the anticolgulant, ethylene diamine tetracetic acid (EDTA) and taken to the laboratory for haematological analysis. The PCV, $\mathrm{Hb}$ concentration and total leucocytes count were evaluated on the $12^{\text {th }}, 24^{\text {th }}$ and $37^{\text {th }}$ weeks of the study. Four samples were collected from each group (treatment). The PCV was determined by the microhaematocril method (Coles, 1986), the $\mathrm{Hb}$ concentration was determined by the cyanomethaemoglobin method (Kachmar, 1970), while the total white blood cell count was determined using the method of Schalm, et al. (1975).

\section{Results and Discussion}

The Table shows the percentage composition of layers diets, while the Figure shows the influence of $\mathrm{CPM}$ on mean periodic haematological characteristics of pullets at the $12^{\text {th }}, 24^{\text {th }}$ and $37^{\text {th }}$ weeks. In weeks 12,24 
and 37, the mean values of PCV were not affected by all the diets. However, mean PVC values in diet $\mathrm{C}$ at the $37^{\text {th }}$ week was significantly higher $(\mathrm{P}<0.05)$ than the value recorded in the control diet. Diets did not affect the $\mathrm{Hb}$ concentration and red blood cells across the weeks. With increasing CPM inclusions in week 24, diets led to a slight increase in the values of total white blood cell counts. The red blood cells of the pullets showed no significant $(\mathrm{P}>0.05)$ difference among the various treatments. Haematological values such as PCV are of great importance in practical husbandry since they reflect the response of the animals to its environment and diseases. They can also act as useful aids to prognosis and may reveal adverse conditions even when the animal did not display obvious clinical signs of ill health (Eze et al.. 2010). The overall range of PCV obtained in this study is generally within the range reported by Bounous and Stedman (2000) as the normal PCV for chickens and turkeys, Sogunle et al. (2009) obtained higher PCV values in growing pullets fed CPM diets supplemented with cashew nut reject meal in 13 weeks old Yaafa Brown pullet chicks. Enyenihi et al. (2008) obtained comparable PCV and WBC values in laying hens fed wetted sun-dried cassava tuber meal, while Oladunjoye et al. (2010) obtained higher PCV values in point of lay Haco strain pullets fed diets containing sun-dried CPM and lyetreated cassava peels. Apart from lower values recorded in all the groups at the $37^{\text {th }}$ week, $\mathrm{Hb}$ concentration values of pullets and layers on all diets in weeks 12 and 24 were within the range established as normal values for chickens (Mituika and Rawnsley, 1977). That the $\mathrm{Hb}$ concentration values did not decline below normal throughout the duration of this study is an indication that anti-nutritional factors which may be present in traces (residual hydrocyanic acid) did not influence this haematological parameter. There is evidence from the results that CPM did not alter the normal values of WBC in the pullets. The implication of these normal ranges observed throughout the study is that the birds were better equipped immunologically to fight infections arising from, micro - organisms which is evident in the low mortality recorded in this study. Also, the RBC values were similar to the reference values documented by Mituika and Rawnsley (1977) for healthy chickens. Hackbath et al. (1983) reported that increased RBC values were associated with high quality dietary protein and with disease- free animals. Enyenihi et al. (2008) and Afolabi et al. (2010) recorded similar RBC values while Sogunle et al. (2009) recorded slightly higher values and observed that RBC increased with increasing CPM inclusions.

\section{Conclusion}

Cassava peel meal at a maximum level of $20 \%$ inclusion in all pullet diets support exchange of substances in the blood as well as work of internal organs. Generally, the PCV, Hb concentration, WBC and RBC values obtained in this study indicate that the birds were healthy and could withstand respiratory stress. This suggests that the different diets were balanced in their formulation to support optimum performance and haematological profiles of the birds.

Table: PERCENTAGE COMPOSITION OF LAYER DIETS

\begin{tabular}{|c|c|c|c|}
\hline \multirow[t]{2}{*}{ Feedstuff } & \multicolumn{3}{|c|}{ Diets } \\
\hline & 1 & 2 & 3 \\
\hline Retted Cassava Peel Meal & 0.00 & 10.00 & 20.00 \\
\hline Fish Meal & 2.00 & 2.00 & 3.00 \\
\hline Soyabean Meal & 30.00 & 30.00 & 25.00 \\
\hline Maize Bran & 9.60 & - & - \\
\hline Maize & 48.00 & 47.60 & 43.70 \\
\hline Bone Meal & 3.50 & 3.50 & 3.50 \\
\hline Limestone & 6.00 & 6.00 & 4.50 \\
\hline Methionine & 0.30 & 0.30 & 0.30 \\
\hline Premix (Layer) & 0.30 & 0.30 & 0.25 \\
\hline Salt & 0.30 & 0.30 & 0.25 \\
\hline Total & 100.00 & 100.00 & 100.00 \\
\hline \multicolumn{4}{|l|}{ Calculated Analysis } \\
\hline Crude Protein \% & 17.51 & 18.20 & 17.40 \\
\hline Energy $\mathrm{Kcal} / \mathrm{kg} \mathrm{ME}$ & 2733 & 2705 & 2630 \\
\hline Calcium \% & 3.50 & 3.67 & 2.93 \\
\hline Phosphorus \% (Total) & 0.845 & 0.840 & 0.851 \\
\hline Methionine \% & 0.574 & 0.592 & 0.541 \\
\hline Lysine \% & 1.020 & 1.022 & 0.921 \\
\hline
\end{tabular}

Layer Bio-organics Premix at the rate of inclusion provides the following additional nutrients per $\mathrm{kg}$ of diet:

Vitamin A 8,500,000.00 i.u., Vit. $\mathrm{D}_{3} 1,500,000.00$ i.u., Vit. E 10, $000 \mathrm{mg}$., Vit. $\mathrm{K}_{3} 1,000 \mathrm{mg}$., Vit. $\mathrm{B}_{1} 1,500$ mg., Vit. $B_{2} 4,500$ mg., Niacine 15,000 mg., Pantothenic Acid, 4,500 mg., Vit. $B_{6} 3,000$ mg., Vit. $B_{12} 15.00$ mg., Folic Acid $600 \mathrm{mg}$., Biotin $\mathrm{H}_{2} 500.00 \mathrm{mg}$., Choline Chloride 175,000.00 mgr., Cobalt $200.00 \mathrm{mg}$., Copper 3,000.00 mg., iodine 1,000 mg., Iron 20,000.00 mg., Manganese 40,000.00 mg., Selenium 200.00 mg., Zinc $30,000.00 \mathrm{mg}$., Antioxidant 1,250.00 mgr. 


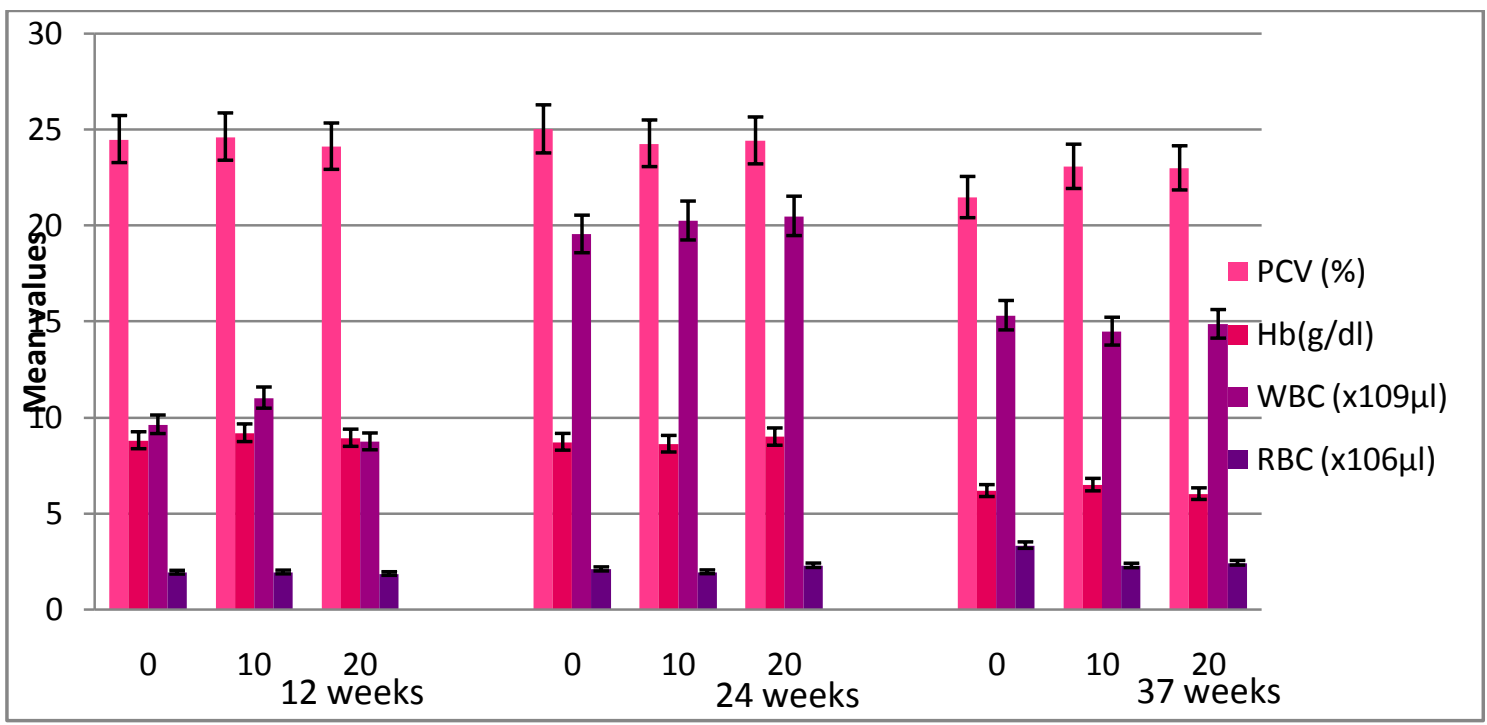

Figure. The influence of cassava peel meal on mean periodic haematological characteristics of pullets at 12 th, 24 th and 37 th weeks

\section{References:}

[1]. Abu, O.A. and Onifade, A.A. (1996). Effects of cassava wastes substitution for maize in weaner rabbit diets. Bull. Anim. Hlth. Prod. Afr., 44:167-172\

[2]. Bounous, D.I. and Stedman, N.L. (2000) Normal avian haematology: chicken and turkey. In : Feldman, B.F. Zinkle, J. G and N.C. Jain Lippin Cott, Williams and Wilkins, Philadelphia, pp; 1147-1154

[3]. Central Bank of Nigeria 2002. Annual Report and Statement of Account. Abuja: CBN.

[4]. Coles, E.H.(1986). Determination of packed cell volume In: Coles E.H. Ed., Veterinary Clinical Pathology: Pp. 17-19: W.B. Saunders Co; Philadelphia.

[5]. Eboh E.C. (2005) Review of Agricultural Research Recommendation and their Policy Implications in Nigeria, African Institute for Applied Economics Enugu, Nigeria Pp 119-158

[6]. Enyenihi, G.E., Udedibie, A.B.I., Akpan, M.J., Obasi , O.L. and Solomon, I.P. (2008). Effects of 5-hour wetting of sun-dried cassava tuber meal on its HCN content, performance and haemotological indices of laying hens. Proceedings of Annual Conf. of the Nig. Soc. for Anim. Prod. held at the University of Calabar.Pp. 402-404.

[7]. Eruvbetine, D., Oguntona, E.B., James, I. J., Osikoya O.V. and Ayodele, S.O. (1996). Cassava (Manihot esculenta) as an energy source in diets for cockerels Int. J. Anim. Sci 11:99-101

[8]. Eze, J.I; Onunkwo, J.I.; Shoyinka, S.V.O.; Cha, F.K.; Ngene, A.A.; Okolinta, N.; Nwanta, J.A.; Onyenwe, I.W. (2010). Haematological profiles of pigs raised under intensive management system in south - eastern Nigeria. Nigerian Veterinary Journal $2010 \operatorname{Vol} 31(2): 115-123$

[9]. Hackbath, H., Buron, K. and Schimansley, G. (1983) Strain difference in inbred rats: Influence of strain and diet on haematological traits. Lab Anim. 17: 7-12

[10]. Ikurior, S.A. and Onuh, S.O. (1996); Assessment of practical potential of cassava peel meal for growing-finishing pigs in sub-humid topics. Bul. Anim. Hlth. Prod. Afri., 44:209-214

[11]. Kachmar, J.F. (1970). Determination of blood haemoglobin by the cyanomethaemoglobin procedure. In: Tietz N.W. Ed., Fundamentals of Clinical Chemistry, W.B Sanders Company, Philadelphia Pp. 268-269

[12]. Mituika, B.T. and Rawnsley, H (1977): Clinical biochemical and haematological value in normal experimental animals. Mason Publishing, N. Y., U.S.A., Pp. 171-174

[13]. Oladunjoye, I.O., Ojebiyi, O. and Amao, O.A.(2010). Effect of feeding processed cassava (Manihot esculenta crantz) peel meal based diet on the performance characteristics, egg quality and blood profile of laying chicken. Agricultural Tropica Et Subtropica Vol. 43 (2). Pp 119-126

[14]. Salami, R.I. (1999). The use of two empirical methods of substitution of feed-stuff: parboiled cassava peel versus maize in the diets of growing cockerels. Nig. J. Anim. Prod., 26: 78-83

[15]. Salami, R.I.(2000).Preliminary studies on the use of parboiled cassava peel meal as a substitute for maize in layers' diets. Trop. Agric, (Trinidad) 77: 199-204

[16]. Schalm, O.W., Jain, N.C. and Carol, E. J. (1975) Veterinary Haematology, $3^{\text {rd }}$ ed. Lea and Fabigar, Philadephia.

[17]. Sogunle, O.M., Fanimo, A.O., Abiola, S.S. and Bamgbose, A.M. (2009). Performance of growing pullets fed cassava peel meal diet supplemented with cashew nut reject meal. Arch. Zootec. 58 (221) : 23-31 .

[18]. Sogunle, O.M., Fanimo, W.O. Biobaku and Bamgbose, A.M. (2003). The feeding value of fullfat cashew nut (Anacardium oocidentale Linn) rejects and low cereal diets for broiler chickens. Nig. J. Anim. Prod., 32: 46-53.

[19]. World Bank 1988. Social Indicators of Development, 1988. Washington, D.C.

[20]. World Bank 1995. Commodity Markets and Developing Countries, A World Bank Quarterly Nov. 